\title{
HUBUNGAN POLA ASUH ORANG TUA DENGAN PERILAKU AGRESIF PADA ANAK USIA REMAJA DI SMA N 1 KAKAS
}

\author{
Inggrid Warouw \\ Jimmy Posangi \\ Yolanda Bataha \\ Program Studi Ilmu Keperawatan Fakultas Kedokteran \\ Universitas Sam Ratulangi \\ Email :inggrid688@gmail.com
}

\begin{abstract}
Abstrack: Adolescent aggressive behavior is an emotional state that is a mixture of feelings of frustration and hatred or anger. This is based on the emotional state in depth of each person as an important part of the emotional state that can be projected into the environment, inside or destructively. One of the factors thant influence aggressive behavior is parenting which is divided into three types, that are authoritarian parenting, permissive pareting, and democratic parenting. The porpose oh this study is to know The Relationship of Parenting Style with Aggressive Behavior Adolescent at SMA N 1 Kakas. The research method uses a cross sectional approach. Respondents consisted of 74 teenage boys in class XI with sampling techniques using Total Sampling. Data collection using a quessionnare. Chi square test result with confidence level of $95 \% \mathrm{v}(\alpha 0.05)$, where the value of $\mathrm{P}=0.023$ is smaller than $\alpha=$ 0.05 . Conclusion there is a relationship between parenting parents with aggressive behavior inadolescent in SMA N 1 Kakas.
\end{abstract}

Keywords: The Relationship of Parenting style, Aggressive Behavior, Adolescent.

\begin{abstract}
Abstrak:Perilaku agresif remaja merupakan suatu keadaan emosi yang merupakan campuran perasaan frustasi dan benci atau marah. Hal ini didasari keadaan emosi secara mendalam dari setiap orang sebagai bagian penting dari keadaan emosional yang dapat diproyeksikan ke lingkungan, ke dalam diri atau secara destruktif. Salah satu faktor yang mempengaruhi perilaku agresif adalah pola asuh orang tua yang terbagi dalam tiga tipe, yaitu pola asuh otoriter, pola asuh permisif, dan pola asuh demokratis. Tujuan peneliti ini adalah mengetahui hubungan pola asuh orang tua dengan perilaku agresif pada anak usia remaja di SMA N 1 Kakas. Metode penelitian menggunakan pendekatan cross sectional. Responden terdiri dari 74 remaja laki-laki kelas XI dengan teknik pengambilan sampel menggunakan Total Sampling. Pengumpulan data menggunakan kuesioner. Hasil Uji Chi Square dengan tingkat kepercayaan $95 \% \mathrm{v}(\alpha 0,05)$, dimana nilai $\mathrm{p}=0,023$ lebih kecil dari $\alpha=0,05$. Kesimpulan ada hubungan antara pola asuh orang tua dengan perilaku agresif pada anak usia remaja di SMA N 1 Kakas.
\end{abstract}

Kata Kunci : Pola asuh orang tua, Perilaku agresif, Remaja.

\section{PENDAHULUAN}

Masa remaja merupakan periode terjadinya pertumbuhan dan perkembangan yang pesat baik secara fisik,psikologis maupun intelektual. Sifat khas remaja mempunyai rasa keingintahuan yang besar, menyukai petualangan dan tantangan serta cenderung berani menanggung resiko atas perbuatannya tanpa didahului oleh pertimbangan yang matang. Apabila keputusan yang diambil dalam menghadapi konflik tidak tepat, mereka akan jatuh ke dalam perilaku berisiko dan mungkin harus menanggung akibat jangka pendek dan jangka panjang dalam berbagai masalah kesehatan fisik dan psikososial. Sifat dan perilaku berisiko ada remaja tersebut memerlukan ketersediaan pelayanan 
kesehatan peduli remaja yang dapat memenuhi kebutuhan kesehatan remaja termasuk pelayanan untuk kesehatan reproduksi (Kementrian Kesehatan RI, 2014)

Tahun 2013 terdapat korban kekerasan psikis sebanyak 520 korban anak sedangkan korban kekerasan fisik sebanyak 450 anak. Korban kebijakan merugikan di Sekolah sebanyak 240, korban bullying 140, korban tawuran sebanyak 50 anak. Data tahun 2014 menunjukkan korban kekerasan psikis sebanyak 660 korban anak sedangkan korban kekerasan fisik sebanyak 610 anak. Korban kebijakan merugikan di Sekolah sebanyak 340, korban bullying 275, korban tawuran sebanyak 110 anak. Data tahun 2015 menunjukkan korban kekerasan psikis sebanyak 100 korban anak sedangkan korban kekerasan fisik sebanyak 90. Korban kebijakan merugikan di Sekolah sebanyak 50, korban bullying 30, korban tawuran sebanyak 10 anak. Pelaku kekerasan ini pada tahun 2013 terdiri dari 135 pelaku bullying dan pelaku tawuran sebanyak 75 anak. Pada tahun 2014 pelaku bullying sebanyak 115 dan pelaku tawuran sebanyak 50 orang. Pada tahun 2015 pelaku bullying ini sebanyak 57 anak dan pelaku tawuran sebanyak 37 anak. Berdasarkan hasil pengamatan peneliti, diketahui ada tiga sekolah yang disebut paling sering terlibat aksi anarkis, yakni SMK Yudya Karya, SMK 45 dan SMK Adipura yang terlibat tawuran pada tahun 2012 terdapat satu kasus tawuran, lalu meningkat menjadi delapan kasus pada tahun 2013. Pada tahun 2014, kasus tawuran naik lagi menjadi 10 kasus. Sedangkan saat ini hampir setiap bulan terjadi satu kali tawuran (Kurniawan, 2014).

Perilaku agresif sering terjadi pada kalangan remaja madya (middle adolescene) dengan rentang usia 15-18 tahun, dimana tanggung jawab hidup yang harus semakin ditingkatkan oleh remaja yang mampu memikul sendiri juga masalah tersendiri bagi remaja madya.
Karena tuntutan peningkatan tanggung jawab tidak hanya datang dari orang tua atau anggota keluarganya tetapi juga dari masyarakat sekitarnya. Tidak jarang masyarakat juga menjadi masalah bagi remaja, tidak jarang remaja mulai meragukan tentang apa yang disebut baik atau buruk. Akibatnya, remaja ingin sering kali membentuk nilai-nilai mereka sendiri yang mereka anggap benar, baik dan pantas untuk dikembangkan di kalangan mereka sendiri. Lebih-lebih jika orang tua atau orang dewasa di sekitarnya ingin memaksakan nilai-nilainya agar dipatuhi oleh remaja tanpa disertai dengan alasan yang masuk akal menurut mereka (Asroli \& Ali, 2009).

Keadaan remaja di Indonesia saat ini sangat memprihatinkan. Hal tersebut dapat dilihat dari kondisi remaja saat ini yang cenderung lebih bebas dan jarang memperhatikan nilai moral yang terkandung dalam setiap perbuatan yang mereka lakukan. Remaja mempunyai sifat yang cenderung lebih agresif, emosi tidak stabil, dan tidak bisa menahan dorongan nafsu. Pada masa pubertas atau masa menjelang dewasa, remaja mengalami banyak pengaruh-pengaruh dari luar yang menyebabkan remaja terbawa pengaruh oleh lingkungan tersebut (Santrock, 2007).

Remaja lebih menunjukkan perilaku agresif dari pada anak-anak dan orang dewasa. Dalam masa yang masih labil, remaja mempunyai kecenderungan yang lebih besar untuk berperilaku agresif. Pengaruh-pengaruh negatif pada remaja sangat beragam, yang pada akhirnya mengarahkan remaja untuk berperilaku agresif. Perilaku agresif pada remaja antara lain seperti perkelahian, tawuran, saling mencaci dan bentuk-bentuk perilaku agresif lainnya (Sinuraya, 2009).

Orang tua dalam keluarga memiliki peranan penting dalam perkembangan dan pendidikan anak, karena sesuatu yang diperbuat oleh orang tua akan berpengaruh terhadap diri anak, sehingga perhatian dan tanggung jawab orang tua sangat diperlukan oleh anak. Hal senada juga 
dikemukakan oleh Sayekti Pujosuwarno yakni; "segala sikap dan tingkah laku orang tua, baik yang disengaja untuk pendidikan maupun yang tidak disengaja untuk pendidikan anak akan berpengaruh terhadap perkembangan dan kepribadian anak". Dari pendapat tersebut, orang tua mempunyai berbagai macam fungsi diantaranya adalah mengasuh anakanaknya. Keluarga merupakan tempat utama dan pertama bagi pendidikan seorang anak, sehingga pembentukan sikap dan kepribadian sangatlah dominan. Hal ini sangat tergantung pada pola asuh yang diberikan orang tua kepada anaknya. Perbuatan dan pola perilaku yang dilakukan orang tua sehari-hari akan dilihat, dinilai dan ditiru oleh anak, sehingga anak akan berbuat dan berperilaku seperti orang tuanya, terlebih bagi anak-anak yang usianya semakin memasuki usia remaja (Wong, 2009).

Orang tua harus diberi semangat untuk menangani perilaku agresif dengan menentukan datas dan harapan yang tegas pada anak. Orang tua dan anak harus memperoleh persesuaian tentang apa yang mereka anggap merupakan tugas-tugas penting dan tanggung jawab anak. Masalah-masalah paling penting perlu ditangani pertama. Ketegasan dan kemandirian sesuai usia harus dikembangkan dan dihargai (Suastini, 2011).

Fenomena yang sangat memprihatinkan adalah aksi-aksi kekerasan baik individualmaupun masal sudah merupakan berita harian di media masa, baik media cetak maupun media elektronik. Aksi- aksi kekerasan dapat terjadi di mana saja, seperti di jalan-jalan, di sekolah, bahkan di komplek perumahan. Aksi tersebut dapat berupa kekerasan verbal (mencaci maki) maupun kekerasan fisik (memukul, meninju dan melukai) (Silitonga, 2009).Berdasarkan urian diatas membuat peneliti tertarik untuk meneliti tentang "Hubungan Pola Asuh Orang Tua Denagn Perilaku Agresif Anak Usia Remaja di SMA N 1 Kakas."

\section{METODE PENELITIAN}

Penelitian ini termasuk dalam jenis penelitian kuantitatif dengan menganalisis gambaran hubungan antara kedua variabel yaitu variabel independen (Pola asuh orang tua) dan variabel dependen (Perilaku agresif).Penelitian ini menggunakan penelitian cross sectional (Setiadi, 2013). Penelitian ini dilaksanakan di SMA N 1 Kakas pada bulan Desember-Maret 2019. Populasi pada penelitian ini adalah remaja di SMA N 1 Kakas dengan jumlah 94orang. Pengambilan sampel menggunakan total sampling. Instrument penelitian yang digunakan yaitu kuesioner Pola asuh orang tua dan Perilaku agesif yang telah di diuji validitasnya. Kuesionerpola asuh orang tua terdiri dari dari 30 pertanyaan dengan menggunakan penilaian $1=$ ya, dan $2=$ tidak. Setelah lembar kuesioner diisi oleh responden, kemudian dilakukan penghitungan skor dengan cara menjumlahkan skor.

Pengukuran perilaku agresif menggunakan kuesioner dengan kriteria skor $5=$ sangat setuju, $4=$ setuju, $3=$ kadangkadang, 2=tidak setuju, 1=sangat tidak setuju. Pengolahan data yang diperoleh dari hasil penelitian ini diolah secara manual dengan mengelompokkan hasil wawancara dan observasi kemudian dilakukan penghitungan skor dan dianalisis menggunakan uji statistik melalui system komuterisasi dengan beberapa tahap yaitu editing, coding, entering, cleaning (Notoatmodjo, 2012). Analisa bivariat dalam penelitian ini yaitu unk mengetahui hubungan antara pola asuh orang tua dengan perilaku agresif pada anak usia remaja menurut kajian model system perilaku Johnson. Peneliti menggunakan uji statistik chi square dengan tingkat kemaknaan $95 \%(\alpha=0,05)$. 
HASIL dan PEMBAHASAN

1. Analisa Univariat

Tabel 1. Distribusi responden berdasarkan pola asuh orang tua

\begin{tabular}{ccc}
\hline $\begin{array}{c}\text { Pola asuh orang } \\
\text { tua }\end{array}$ & n & \% \\
\hline Otoriter & 28 & 37.8 \\
Demokratis & 29 & 39.2 \\
Permisif & 17 & 23.0 \\
\hline Total & $\mathbf{7 4}$ & $\mathbf{1 0 0 \%}$ \\
\hline Sumber:
\end{tabular}

Sumber: Data primer, 2019

Tabel 1 menunjukkan bahwa responden pola asuh yang paling banyak diterapkan adalah pola asuh demokratis sebanyak $77.0 \%$ (29 orang),pola asuh otoriter 37.8 $\%$ (28 orang) dan paling sedikit adalah pola asuh permisif $23 \%$ (17 orang).

Tabel 2. Distribusi responden berdasarkan Perilaku Agresif

\begin{tabular}{ccc}
\hline Perilaku agresif & n & \% \\
\hline Tinggi & 42 & 56.8 \\
Rendah & 32 & 43.2 \\
\hline Total & $\mathbf{7 4}$ & $\mathbf{1 0 0 \%}$ \\
\hline
\end{tabular}

Sumber: Data primer, 2019

Tabel 2 menunjukkan responden paling banyak adalah responden berperilaku agresif tinggi sebanyak $56.8 \%$ (42 orang) dan yang paling sedikit adalah responden berperilaku agresif rendah sebanyak $43.2 \%$ (32orang).

\section{Analisa Univariat}

Tabel 3. Hubungan pola asuh orang tua dengan perilaku agresif pada anak usia remaja di SMA N 1 Kakas

\begin{tabular}{lccccccc}
\hline \multirow{2}{*}{$\begin{array}{c}\text { Pola Asuh } \\
\text { Trang }\end{array}$} & \multicolumn{6}{c}{ Tinggi } & \multicolumn{2}{c}{ Rendah } & \multicolumn{2}{c}{ Total } & \multirow{2}{*}{$\begin{array}{c}\text { P } \\
\text { Value }\end{array}$} \\
\cline { 2 - 6 } & $\mathrm{n}$ & $\%$ & $\mathrm{n}$ & $\%$ & $\mathrm{n}$ & $\%$ & \\
\hline Otoriter & 18 & 24.3 & 10 & 13.5 & 28 & 37.8. & \\
Demokratis & 11 & 14.9 & 18 & 24.3 & 29 & 39.2 & \multirow{2}{*}{0,023} \\
Permisif & 13 & 17.6 & 4 & 5.4 & 17 & 23.0 & \\
\hline Total & 42 & 100.0 & 32 & 100.0 & 74 & 100.0 & \\
\hline
\end{tabular}

Sumber : Data Primer 2019
Tabel 3 Hasil penelitian dari 74 responden menunjukkan bahwa dari 74 sampel yang mendapatkan pola asuh otoriter didapatkan 18 responden berperilaku agresif tinggi,10 responden berperilaku agresif rendah, kemudian pola asuh demokratis didapatkan 11 responden beperilaku agresif tinggi, 18 responden berpeilaku agresif rendah dan pola asuh permisif didapatkan 13 responden berperilaku agresif tinggi kemudian 4 responden berperilaku agresif rendah. Hasil uji hipotesa dengan menggunakan uji Chi - Square dengan tingkat kepercayaan $95 \% \quad(\alpha \quad 0,05)$, menunjukan adanya hubungan yang signifikan antara pola asuh orang tua dengan perilaku agresif dimana $p$-value $=$ 0,023 lebih kecil dari $\alpha=0,05$. Analisa hasil uji hipotesis dari pola asuh orang tua dengan perilaku agresif menggunakan uji chi-square pada tingkat kemaknaan 95\% $(\alpha=0,05 \%)$, dari hasil penelitian yang telah dilakukan menunjukkan adanya hubungan antara pola asuh orang tua dengan perilaku agresif pada anak usia remaja di SMA N 1 Kakas. Dimana nilai $p$-value $=0,023$ lebih kecil dari $\alpha=0,05$. Hal ini sesuai dengan penelitian yang dilakukan oleh Dwi Karunia Saputra, Dian Ratna Sawitri (2015) dimana terdapat hubungan antara pola asuh orang tua dengan perilaku agresif pada remaja pertengahan di SMK Hidayah Semarang. Pentingnya faktor keluarga untuk dipertimbangkan ketika menyoroti agresivitas pada remaja dikemukakan oleh (Parazayu, 2018), yang mengatakan bahwa orang tua yang sering memberikan hukuman fisik pada anaknya dikarenakan kegagalan memenuhi standar yang telah ditetapkan oleh orang tua. Hal ini membuat anak marah dan kesal kepada orang tuanya tetapi anak tidak berani mengungkapkan kemarahannya dan melampiaskannya kepada orang lain dalam bentuk perilaku agresif. Orang tua yang terlalu menuntut membuat anak menjadi frustrasi.

Hasil crosstab penelitian untuk responden dengan pola asuh orang tua otoriter yang 
memiliki perilaku agresif tinggi sebanyak 18 orang dan memiliki perilaku agresif rendah sebanyak 10 orang. Orang tua yang menerapkan pola asuh otoriter akan menekankan adanya kepatuhan seorang anak terhadap peraturan yang mereka buat tanpa banyak basa-basi, tanpa banyak penjelasan kepada anaknya mengenai sebab diberlakukannya peraturan tersebut, cenderung menghukum anaknya yang melanggar peraturan atau menyalahi norma yang berlaku. Orang tua demikian berkeyakinan bahwa cara yang keras merupakan cara yang terbaik dalam mendidik anaknya. Begitupun dengan anak, ia akan melakukan peniruan terhadap pendidikan yang diberikan oleh orang tuanya tersebut terkait dengan cara-cara penerapan peraturan, cara bersikap, dan dampak hukuman kedepannya, akan membuat anak terpengaruh untuk mengikuti sikap tersebut, sehingga jika orangtua bersikap keras, maka cenderung anak juga akan bersikap keras. Sehingga dari adanya pemberian contoh sikap yang keras tersebut, cenderung anak akan meniru perilaku tersebut, sehingga anak tersebut akan berperilakuagresif (Saputra, 2015).

Berdasarkan asumsi peneliti, hasil penelitian dan beberapa teori, serta penelitian yang terkait yang menunjukkan adanya hubungan yang signitifkan antara pola asuh orang tua dengan perilaku agresif pada anak usia remaja, hal ini didukung oleh penelitian yang dilakukan Empati, dkk (2015) terdapat hubungan positif dan signifikan antara pola asuh otoriter orang tua dengan agresivitas pada pada remaja usia pertengahan di SMK Hidayah Semarang, peneliti juga

Sinuraya, D. (2009). Hubungan antara kepribadian ekstrovert dengan perilakuagresif pada remaja.skripsi. Yogyakarta: Universitas Muhammadiyah Surakarta

Suastini, N. W. (2011). Hubungan Antara Pola Asuh Orang Tua Otoriter berasumsi ada hubungan yang signitif antara pola asuh orang tua dengan perilaku agresif pada anak usia remaja, karena semakin tinggi pola asuh otoriter orang tua maka semakin tinggi agresivitas remaja. Begitu pula sebaliknya, semakin rendah pola asuh otoriter orang tua maka semakin rendah agresivitas remaja.

\section{SIMPULAN}

Berdasarkan hasil peneliti yang diperoleh, dapat ditarik kesimpulan bahwa terdapat hubungan antara pola asuh orang tua dengan perilaku agreisif paa anak usia remaja di SMA N 1 Kakas. Hal tersebut berarti semakin tinggi pola asuh otoriter orang tua maka semakin tinggi agresivitas remaja. Begitu pula sebaliknya, semakin rendah pola asuh otoriter orang tua maka semakin rendah agresivitas remaja. Remaja laki-laki di SMA N 1 Kakas memiliki tingkat perilaku agresif tinggi.

\section{DAFTAR PUSTAKA}

Asroli, M. \& Ali, M.(2009). psikologi remaja perkembangan peserta didik cetakan 5. Jakarta: PT. Bumi Aksara.

Dwi Karunia Saputra, Dian Ratna Sawitri. (2015). Pola Asuh Otoriter Orang Tua dan Agresivitas pada Remaja Pertengahan di SMK HIDAYAH Semarang.

Semarang.https://media.neliti.com/med ia/publications/64492-ID-pola-asuhotoriter-orang-tua-dan-agresiv.pdf. Diakses 25 maret 2019

Empati, J., Einstein, G., \& Indrawati, E. S. (2016). Hubungan Antara Pola Asuh Otoriter Orangtua Dengan Perilaku Agresif 
e-journal Keperawatan(e-Kp) Volume 7 Nomor 1, Mei 2019

Dengan Agresif Remaja Di SMP 2

Denpasar.

Wong, D. L. (2009) Buku Ajar Keperawatan Pedriatric. Edisi 6 Volume 1 Jakarta EGC.

Setiadi (2013). Konsep dan Praktek Penulisan Riset Keperawatan (Edisi 2). Yogyakarta: Graha Ilmu

Silitonga, M., Yulastri, L., \& Artanti, G. D. (n.d.). Hubungan Pola Asuh Orangtua Dengan Agresivitas Anak di SMPN 194 Jakarta Timur, 7-11.

Santrock, J.W. (2007). Adolescence: Perkembangan remaja. Jakarta: Erlangga

Kementerian Kesehatan RI. (2014). Pusat Data dan Informasi. t.t. Situasi Kesehatan Reproduksi Remaja. Jakarta Selatan.

Kurniawan, A. (2014). Ari Kurniawan, 2014 Efektivitas Konseling Kelompok Teman Sebaya Dalam Mereduksi Perilaku Agresif Siswa Universitas Pendidikan Indonesia.

Notoatmodjo, (2010). Metodologi Penelia=tian Kesehatan. Jakarta: Rineke Cipta

Parasayu z. (2018). Hubungan antara konformitas dan prilaku agresif pada remaja. 